\title{
Methodology of the tetrazolium test for identifying viable seeds of orchids of the genus Cattleya native to the Brazilian Cerrado
}

\section{Metodologia do teste de tetrazólio para identificação de sementes viáveis de orquídeas do gênero Cattleya nativas do Cerrado brasileiro}

\author{
Luan Marlon Ribeiro ${ }^{1 *}$; José Carlos Sorgato2; Jackeline Schultz Soares ${ }^{3 ;}$ \\ Jéssica Celeste Mônico Ramos ${ }^{1}$
}

Highlights

The highest viability values were close to germination percentages for both species.

Ambient temperature aided in the accuracy of the tetrazolium test for both species.

These results may help to conserve these species in Brazilian Cerrado.

\begin{abstract}
Orchids need measures for conservation of their species, among them the creation of seed banks. This study analyzes suitable methodologies to identify the viability of Cattleya seeds through the tetrazolium test. Seeds of Cattleya nobilior Rchb. and Cattleya walkeriana Gardn. were submitted to three preconditioning: no soaking (control); sucrose (10\%); or distilled water. After 24 hours, they were submitted to tetrazolium solution with three types of conditioning: oven $\left(40^{\circ} \mathrm{C}\right)$; water bath $\left(40^{\circ} \mathrm{C}\right)$; or room temperature. Subsequently, the percentage of viable seeds (VS) was calculated and in vitro sowing was carried out. Germination percentage (G) was determined after 45 days. A completely randomized design was used for each species studied, with treatments arranged in a $3 \times 3$ factorial scheme (three preconditioning and three conditioning), with eight replicates of one tube each. The experiment was performed in duplicate. The highest viability values found in the tetrazolium test were close to those of germination (C. nobilior: VS $=88 \%$ e G $=97 \%$; . walkeriana: VS $=88 \%$ e G $=95 \%$ ) for Cattleya species native to the Cerrado. The conditioning at ambient temperature had a greater effect on seed visualization for both species studied, suggesting that the tetrazolium test should be performed at this conditioning temperature.
\end{abstract}

Key words: Seed bank. Native species. Orchidaceae. Viability test.

1 Students of the Postgraduate Program in Plant Production, Federal University of Grande Dourados, UFGD, Dourados, MS, Brazil. E-mail: luanmarlon@hotmail.com; jessica_monico13@hotmail.com

2 Prof. Dr., UFGD, Dourados, MS, Brazil. E-mail: josesorgato@ufgd.edu.br

${ }^{3} \mathrm{Dr}^{\mathrm{a}}$, Researcher, UFGD, Dourados, MS, Brazil. E-mail: jacke.schultz@gmail.com

* Author for correspondence

Received: May 20, 2020 - Approved: Oct. 27, 2020 


\section{Resumo}

As orquídeas necessitam de medidas para a conservação de suas espécies, entre essas a criação de bancos de sementes. Objetivou-se identificar metodologia adequada para a identificação da viabilidade de sementes de Cattleya por meio do teste de tetrazólio. Sementes de Cattleya nobilior Rchb. e Cattleya walkeriana Gardn. foram submetidas a três pré-condicionamentos: sem embebição (controle); sacarose (10\%) ou água destilada. Decorridas 24 horas, foram submetidas à solução de tetrazólio, com três tipos de condicionamento: estufa $\left(40^{\circ} \mathrm{C}\right)$, banho maria $\left(40^{\circ} \mathrm{C}\right)$ ou temperatura ambiente. Após esse período foi calculada a porcentagem de sementes viáveis (SV). Foi realizada a semeadura in vitro e, após 45 dias, determinada a porcentagem de germinação (G). Para cada espécie estudada, foi utilizado o delineamento inteiramente casualizado e os tratamentos foram arranjados em esquema fatorial $3 \times 3$ (três précondicionamentos e três condicionamentos) com oito repetições de um tubo de ensaio cada, sendo o experimento realizado em duplicata. Os maiores valores de viabilidade encontrados no teste de tetrazólio foram próximos aos de germinação (C. nobilior: SV = 88\% e G = 97\%; C. walkeriana: SV = 88\% e G = 95\%) para essas espécies de Cattleya nativas do Cerrado. Para as duas espécies estudadas, o condicionamento em temperatura ambiente apresentou melhor visualização das sementes, sugerindo que o teste de tetrazólio deve ser realizado nesta temperatura de condicionamento.

Palavras-chave: Banco de sementes. Espécies nativas. Orchidaceae. Teste de viabilidade.

Orchids stand out among ornamental plants because of their ability to combine genetics, beauty, color diversity, shape, and flower durability (Zahara, Datta, Boonkorkaew, \& Mishra, 2017). According to Fay (2018), epiphytic species also have great ecological importance in forest communities, contributing to the maintenance of biodiversity. Moreover, some genera also have food and pharmacological potential.

In Brazil, the family consists of 206 genera, comprising 2.391 species, out of which 1.539 are endemic. The Brazilian Cerrado is home to 670 species, distributed in 114 genera, with Orchidaceae being the third most representative family in plant biodiversity (Flora do Brasil, 2020).

A total of 111 species of Cattleya are found in Brazil. Among these species is $C$. nobilior Rchb.f., which is small (5 to $10 \mathrm{~cm}$ ), having rupicolous or epiphytic habit, dark pink or light pink-lilac flowers, and trilobed lip.
AccordingtoFloradoBrasil, thisspeciesisnative and is distributed in the midwest, northeast, and north regions. In turn, C. walkeriana Gardn. is a rupicolous or epiphytic species, native and endemic to Brazil, distributed in the midwest, north, and southeast regions (Flora do Brasil, 2020). It is a small plant (pseudobulbs up to 10 $\mathrm{cm})$, dark pink to light pink-lilac flowers, and trilobed lip (Araújo, 2017).

These plants have a highly specialized life cycle. Their seeds have little or no nutritional reserves and germination in natural environment is dependent on the association with mycorrhizal fungi. This characteristic coupled to extractivism, results in vulnerability of this family, which is among the most seriously endangered (Fay, 2018; Suzuki, Bertoncelli, Alves, \& Faria, 2018).

In this sense, conservation of native species requires the association of in situ and ex situ conservation methods, such as in vitro propagation and seed bank formation (Fay, 
2018). Thus, storing orchid seeds can be a simple way to conserve the genetic variability of species (Seaton et al., 2018; Hengling, Gianeti, Hosomi, Machado, \& Custódio, 2020). Notwithstanding, seed viability can be affected even if seeds are stored under appropriate conditions (Hosomi, 2017).

The tetrazolium test $(2,3,5$ tetrazolium triphenyl chloride) is used to identify the quality of orchid seeds because it is an easy test that provides fast results. However, factors such as pre-treatments, the test solution concentration and exposure time may affect the results (Hosomi, Santos, Custódio, \& Machado, 2011; Soares, Rosa, Tatara, Sorgato, \& Lemes, 2014). Information about methods to perform this test for native species is still scarce, especially for orchid species in the Brazilian Cerrado (Hosomi, 2017). Furthermore, there is no specification for performing this test on orchids in the rules for seed analysis (RAS) (Ministério da Agricultura, Pecuária e Abastecimento [MAPA], 2009).

Given the ecological and economic importance of Cerrado orchid species, this study analyzed suitable methodologies to identify the seed viability of species Cattleya nobilior Rchb. and Cattleya walkeriana Gardn. by the tetrazolium test.

The experiment was developed at the in vitro Culture Laboratory of the School of Agrarian Sciences of the Federal University of Grande Dourados-UFGD. Cattleya nobilior seeds were obtained from a Private Natural Heritage Reserve, located under the coordinates $21^{\circ} 29^{\prime} 31^{\prime \prime} \mathrm{S}$ and $56^{\circ} 24^{\prime} 11^{\prime \prime} \mathrm{W}$, and Cattleya walkeriana Gardn. seeds were donated by the researcher Dr. Renato F. Galdiano Júnior.
Closed capsules were collected eleven months after pollination and opened with a scalpel. Their seeds were removed, homogenized, and conditioned in a desiccator with silica gel $\left(25 \pm 2^{\circ} \mathrm{C}, 75 \% \mathrm{RH}\right)$ for 15 days. Seeds of each species were separately packaged in aluminum foil, stored in opaque polypropylene screw-capped vials containing silica gel, and refrigerated at $4 \pm 2{ }^{\circ} \mathrm{C}$ for up to 180 days.

According to methodology adapted from Hosomi, Souza, Custódio and Machado (2017), forty-eight $0.001 \mathrm{~g}$ samples of stored seeds of each species were placed in test tubes. Sets of twelve $10 \mathrm{~mL}$ tubes were subjected to preconditioning $(P)$ with three soaking pretreatments: P1 - no soaking (control); P2 - 3 $\mathrm{mL}$ of sucrose solution (10\%) for 24 hours; and P3 - $3 \mathrm{~mL}$ of distilled water for 24 hours.

Twenty-four hours after preconditioning, the seeds were washed with distilled water, being then subjected to a $3 \mathrm{~mL}$ aqueous solution of 2,3,5 triphenyl tetrazolium chloride $(0.5 \%)$ and transferred to the dark for 24 hours, with three conditioning treatments (C): $\mathrm{C} 1$ - oven $\left(40^{\circ} \mathrm{C}\right) ; \mathrm{C} 2$ - water bath $\left(40^{\circ} \mathrm{C}\right)$; and $\mathrm{C} 3$ - ambient temperature $\left(25 \pm 2{ }^{\circ} \mathrm{C}\right)$, with eight replicates of one tube each.

After 24 hours, the suspensions were added with $7 \mathrm{~mL}$ of distilled water and shaken. Then, $1 \mathrm{~mL}$ was pipetted in a Peters chamber to identify and count viable seeds with the aid of a binocular stereoscopic zoom microscope. Seeds with totally carmine embryos; with partially colored embryos; with colorless embryos; and embryo-free seeds were counted. The percentage of viable seeds (\%VS) was calculated by the following formula:

$$
\% \mathrm{VS}=\frac{\text { number of seeds with totally carmine embryos } \mathrm{x} 100}{\text { total number observed seeds }}
$$


Treatments were photographed with the aid of a digital camera coupled to the stereoscopic microscope, using the AxionVision version 3.1 (Zeiss $^{\circledR}$ ) software.

After the test, a sample of $0.005 \mathrm{~g}$ of seeds of each studied species was taken to an aseptic environment and disinfected with $15 \mathrm{~mL}$ of $0.8 \%$ sodium hypochlorite solution, remaining immersed for five minutes. The seed suspension was diluted to $50 \mathrm{~mL}$, being washed three times with sterile distilled water (121 ${ }^{\circ} \mathrm{C}$ and 1 atm pressure for 20 minutes). Subsequently, the suspension volume was made up to $50 \mathrm{~mL}$ with sterile distilled water. For in vitro sowing, $1000 \mu \mathrm{L}$ of seed suspension was inoculated per vial, totaling four culture vials for each species.
Sixty (60) $\mathrm{mL}$ of Murashige \& Skoog (1962) formulated culture medium (MS) at half the normal salt concentration $(1 / 2 \mathrm{MS})$ was used per $600 \mathrm{~mL}$ vial. Subsequently, cultures were placed in a growth room under controlled temperature and photoperiod $\left(25 \pm 2{ }^{\circ} \mathrm{C} ; 16\right.$ h), and $22 \mu \mathrm{mol} \mathrm{m} \mathrm{m}^{-2} \mathrm{~s}^{-1}$ irradiance provided by white fluorescent lamps.

Germination percentage was evaluated after 45 days of cultivation. For this purpose, $10 \mathrm{~mL}$ of distilled water were added to each culture vial. After manual shaking, the seed suspension was poured into a Petri dish and the total number of seeds and number of germinated seedlings were counted using a binocular stereoscopic zoom microscope. Germination percentage (\%G) was calculated using the following formula:

$$
\% \mathrm{G}=\frac{\text { number of germinated seedlings } \mathrm{x} 100}{\text { total number observed seeds }}
$$

A completely randomized design (CRD) was used for each species studied, with treatments arranged in a $3 \times 3$ factorial scheme (three preconditioning and three conditioning), eight replicates of one tube each. The experiment was performed in duplicate. Data were subjected to analysis of variance. When significant, means were compared by the Tukey test $(p<0.05)$. The statistical analyses were conducted using the SISVAR v.5.3. software (Federal University of Lavras, MG, Brazil).

There was a combined effect $(p<0.05)$ of preconditioning and conditioning on the percentage of viable seeds (\%VS) for both species. For C. nobilior, the highest values of \%VS were observed when seeds were preconditioned in distilled water for 24 hours and, subsequently conditioned in ambient temperature (88\%), although without statistical difference from those seeds preconditioned in distilled water and conditioned in oven (87\%), those preconditioned in sucrose (87\%) and conditioned in ambient temperature (87\%) and those preconditioned in control and conditioned in C3 (83\%) (Table 1). 
Table 1

Percentage of viable seeds (\%VS) of Cattleya nobilior Rchb. as a function of preconditioning and conditioning in the tetrazolium test

\begin{tabular}{|c|c|c|c|}
\hline \multirow{3}{*}{ Preconditioning } & \multicolumn{3}{|c|}{$\%$ VS } \\
\hline & \multicolumn{3}{|c|}{ 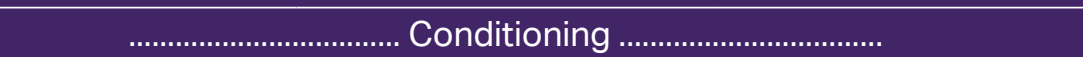 } \\
\hline & Oven (C1) & Water bath (C2) & Ambient temp. (C3) \\
\hline Control (P1) & $9 \mathrm{bB}$ & $11 \mathrm{bB}$ & $83 \mathrm{aA}$ \\
\hline Sucrose (P2) & $87 \mathrm{aA}$ & $66 \mathrm{aB}$ & $87 \mathrm{aA}$ \\
\hline Distilled water (P3) & $87 \mathrm{aA}$ & $60 \mathrm{aB}$ & $88 \mathrm{aA}$ \\
\hline Average & 61 & 46 & 86 \\
\hline C.V. \% & & 14.11 & \\
\hline
\end{tabular}

Means followed by the same lowercase letter in the column and uppercase letter in the row do not differ by the Tukey test $(p<0.05)$.

For C. walkeriana, the highest \%VS value was observed when seeds were preconditioned in sucrose and subsequently conditioned in ambient temperature (88\%), not differing statistically between preconditioning control and distilled water with subsequent conditioning in ambient temperature (67 and $69 \%$, respectively) and neither of the preconditioning or sucrose in the conditioning water bath (68\%) (Table 2).

\section{Table 2}

Percentage of viable seeds (\%VS) of Cattleya walkeriana Gardn. as a function of preconditioning and conditioning in the tetrazolium test

\begin{tabular}{|c|c|c|c|}
\hline \multirow{3}{*}{ Preconditioning } & \multicolumn{3}{|c|}{$\%$ VS } \\
\hline & \multicolumn{3}{|c|}{ 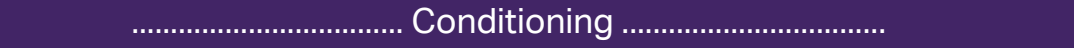 } \\
\hline & Oven (C1) & Water bath (C2) & Ambient temp. (C3) \\
\hline Control (P1) & $10 \mathrm{bB}$ & $9 \mathrm{bB}$ & $67 \mathrm{aA}$ \\
\hline Sucrose (P2) & $37 \mathrm{aB}$ & 68 aA & 88 aA \\
\hline Distilled water (P3) & $27 \mathrm{abB}$ & 56 aA & 69 aA \\
\hline Average & 25 & 44 & 74 \\
\hline C.V. \% & & 24.21 & \\
\hline
\end{tabular}

Means followed by the same lowercase letter in the column and uppercase letter in the row do not differ by the Tukey test $(p<0.05)$.

Hosomi et al. (2017) point out that the use of different seed preconditioning and conditioning treatments may facilitate the penetration of tetrazolium solution into the tissues to be evaluated. The results of this study allow us to infer that seed conditioning 
at ambient temperature aided in the accuracy of the tetrazolium test for both $C$. nobilior and C. walkeriana. Thus, the temperature during the test may be a determining factor in improving the visualization of viable seeds of these species.

When studying species of the same genus but native to the Atlantic Forest (Cattleya labiata Lindl. and Cattleya tigrina A.Rich.), these same authors observed that the use of $10 \%$ glucose or sucrose solution in preconditioning resulted in better seed visualization during the tetrazolium test. However, the temperature during the test was more important than the preconditioning of seeds for the species used in the present study.
According to Carneiro (2014), this variation of responses to the tetrazolium test among orchid species from different biomes may be related to the great diversity of the Orchidaceae family. Furthermore, R. S. Oliveira, Batista, Proença and Biachetti (1996) point out that Cerrado orchid species, mainly those of the genus Cattleya, adapt to long periods of drought and resist to low relative humidity, which reduces tissue dehydration and may influence their seed physiology.

The results observed for the two Cattleya species (Figures 1 and 2) suggest that specific protocols should be used when conducting the tetrazolium test for better visualization of viable orchid seeds.
C1

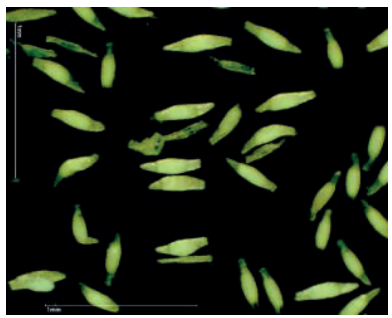

P1

P2

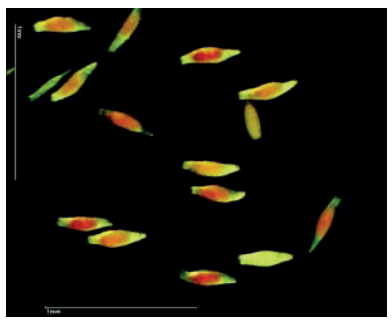

P3

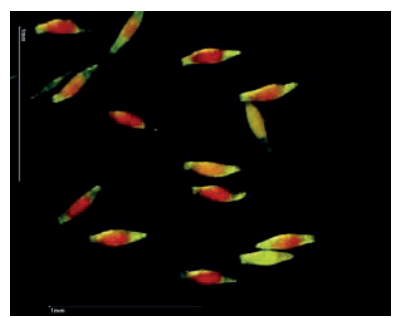

C2
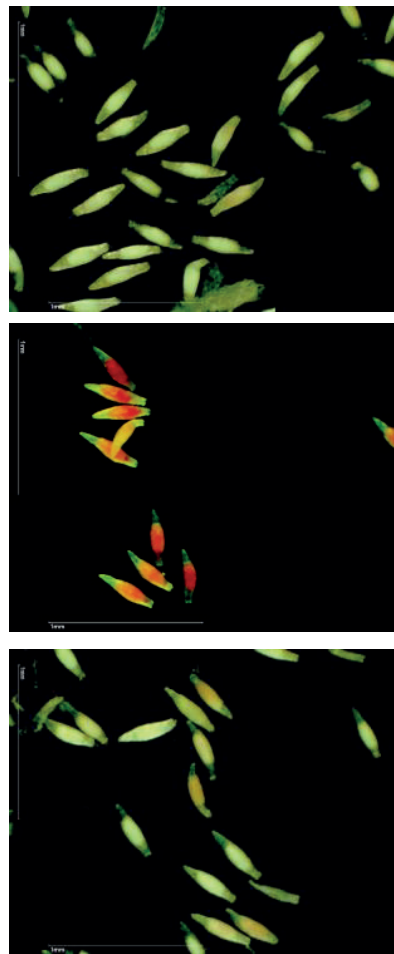

C3
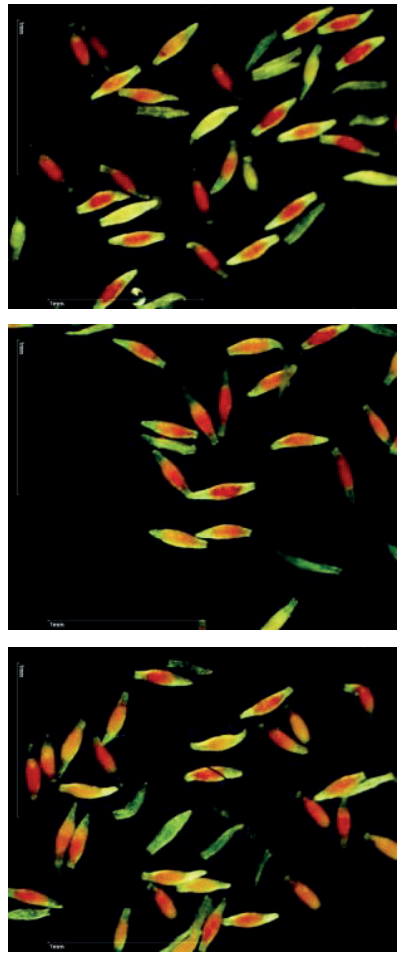

$1 \mathrm{~mm}$

Figure 1. Cattleya nobilior Rchb. seeds as a function of preconditioning (P1 - no soaking (control); P2 - $3 \mathrm{~mL}$ of sucrose solution (10\%) for 24 hours; and P3 - $3 \mathrm{~mL}$ of distilled solution for 24 hours) and conditioning (C1 - oven, $40{ }^{\circ} \mathrm{C}$; $\mathrm{C} 2$ - water bath, $40^{\circ} \mathrm{C}$; and $\mathrm{C} 3$ - ambient temperature, $\left(25 \pm 2^{\circ} \mathrm{C}\right)$ in the tetrazolium test. 
C1

P1

P2

P3

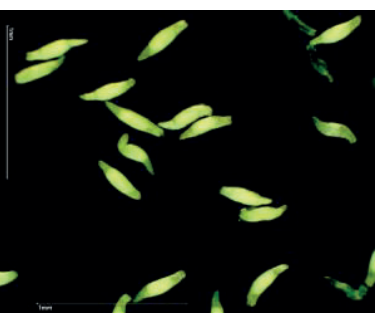

$\mathrm{C} 2$
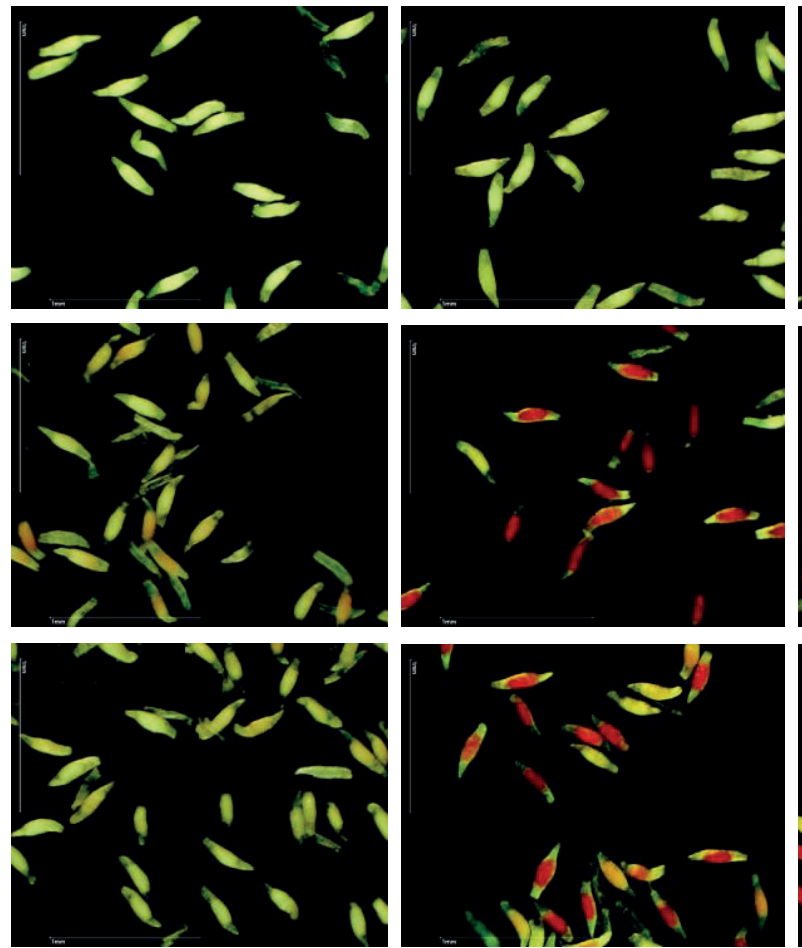

C3
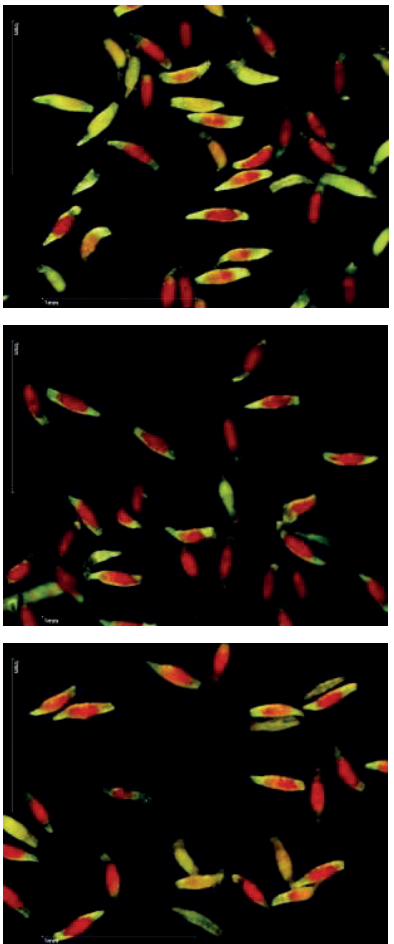

$1 \mathrm{~mm}$

Figure 2. Cattleya walkeriana Gardn. seeds as a function of preconditioning (P1 - no soaking (control); P2 - $3 \mathrm{~mL}$ of sucrose solution (10\%) for 24 hours; and P3 - $3 \mathrm{~mL}$ of distilled solution for 24 hours) and conditioning (C1 - oven, $40{ }^{\circ} \mathrm{C}$; $\mathrm{C} 2$ - water bath, $40^{\circ} \mathrm{C}$; and $\mathrm{C} 3$ - ambient temperature, $25 \pm 2^{\circ} \mathrm{C}$ ) in the tetrazolium test.

The highest viability values found in the tetrazolium test were close to those of germination $(\% \mathrm{G})$ in the two species studied. At 45 days after sowing, C. nobilior showed $\% \mathrm{VS}=86 \%( \pm 2.92)$ and $\% \mathrm{G}=97 \%( \pm 1.12)$, with correlation coefficient of -0.002 . While $C$. walkeriana showed $\% \mathrm{VS}=74 \%( \pm 11.40)$ and $\% \mathrm{G}=95 \%( \pm 0.67)$, with correlation coefficient of 0.055 .

The results of viable seeds (close but inferior to germination) can be explained by the mode of action of the test, since it reflects the activity of dehydrogenase enzymes involved in the respiration process, making it possible to distinguish between the living parts of the seeds and the dead ones, which do not change color (L. M. Oliveira, Carvalho, \& Davide, 2005). The rules for seed analysis (MAPA, 2009) recommend that partially colored embryos may or may not be viable, since the position and size of necrotic areas is what determines seed viability. Thus, the highest \%G values may have occurred because seeds that were considered inviable in the tetrazolium test may have germinated under appropriate conditions.

Hengling et al. (2020), studying Cattleya species from other Brazilian Biomes, observed lower \%Gand higher\%VS values for tetrazolium 
test. The authors report that the germination is a very complex event, while the tetrazolium test evaluates the enzyme activities in the airway of the seed. These data suggest that both tests can be used to evaluate native orchid seeds.

For species Cattleya nobilior and Cattleya walkeriana, native to the Cerrado, the tetrazolium test should be performed at ambient temperature independent of the preconditioning used. Considering the importance of species conservation, this procedure facilitates the identification of viable seeds among germplasm lots.

\section{Acknowledgments}

The authors thank CAPES and UFGD (Brazil) for the scholarships granted, for technical and financial assistance. We also thank Dr. Renato F. Galdiano Júnior for donating C. walkeriana seeds.

\section{References}

Araújo, R. (2017). Orquídeas Walkeriana. São Paulo, SP: Editora Europa.

Flora do Brasil (2020). Jardim Botânico do Rio de Janeiro. Rio de Janeiro, RJ: JBRJ. Recuperado de http://floradobrasil.jbrj. gov.brl

Carneiro, L. L. (2014). Pré-melhoramento genético, floraçãoinvitroecriopreservação de orquídeas nativas do Cerrado. Tese de doutorado, Universidade Federal de Goiás, Goiânia, GO, Brasil.

Fay, M. F. (2018). Orchid conservation: how can we meet the challenges in the twenty-first century? Botanical Studies, 59(16), 1-6. doi: 10.1186/s40529-018-0232-z
Hengling, M. M., Gianeti, T. M., Hosomi, S. T., Machado, N. B., Neto, \& Custódio, C. C. (2020). Storage of Brazilian Cattleya seeds from diverse biomes: lipid composition and effects on germination. Plant BiosystemsAn International Journal Dealing with all Aspects of Plant Biology, 11(1), 1-16. doi: 10.1080/ 11263504.2020.1762781

Hosomi, S. T. (2017). Sementes de orquídeas: conservação e avaliação de viabilidade. Tese de doutorado, Universidade do Oeste Paulista, Presidente Prudente, SP, Brasil.

Hosomi, S. T., Santos, R. B., Custódio, C. C., \& Machado, N. B., Neto. (2011). Preconditioning Cattleya seeds to improve the efficacy of the tetrazolium test for viability. Seed Science and Technology, 39(1), 178-189. doi: 10.15258/ sst.2011.39.1.15

Hosomi, S. T., Souza, T. B., Custódio, C. C., \& Machado, N. B., Neto. (2017). Refining the tetrazolium test for evaluation of Cattleya labiata and C. tigrina seeds viability. Australian Journal of Crop Science, 11(10), 1320-1326. doi: 10.21475/ajcs.17.11.10. pne606

Ministério da Agricultura, Pecuária e Abastecimento (2009). Regras para análise de sementes. Brasília, DF: MAPA. Recuperado de https://www.abrates.org. br/files/regras_analise_de_sementes.pdf

Murashige, T., \& Skoog, F. A. (1962). A revised medium for rapid growth and bioassays with tobacco tissue culture. Physiology Plantarum, 15(1), 473-497. doi: 10.1111/j. 1399-3054.1962.tb08052.x

Oliveira, L. M., Carvalho, M. L. M., \& Davide, A. C. (2005). Teste de tetrazólio para avaliação de sementes de Peltophorum 
dubium (Sprengel) Taubert - leguminosae caesalpinioideae. Cerne, 11(2), 159-166.

Oliveira, R. S., Batista, J. A. N., Proença, C. E. B., \& Bianchetti, L. (1996). Efeito do fogo na floração de espécies de Orchidaceae em Cerrado. In H. S. Miranda, B. F. S. Dias, \& C. H. Saito (Eds.), Impacto de queimadas em área de Cerrado e restinga (pp. 61-67). Brasília, DF: Universidade de Brasília.

Seaton, P.T., Hosomi, S. T., Custódio, C. C., Marks, T. R., Machado, N. B., Neto, \& Pritchard, H. W. (2018). Orchid seed and pollen: a toolkit for long-term storage, viability assessment and conservation. In Y. Lee, \& E. C. Yeung (Eds.), Orchid propagation: from laboratories to greenhouses - methods and protocols (pp. 71-98). New York, NY: Humana press.
Soares, J. S., Rosa, Y. B. C. J., Tatara, M. B., Sorgato, J. C., \& Lemes, C. S. R. (2014). Identificação da viabilidade de sementes de orquídeas pelo teste de tetrazólio. Semina: Ciências Agrárias, 35(5), 22752284. doi: 10.5433/1679-0359.2014v35n $5 p 2275$

Suzuki, A. B. P., Bertoncelli, D. J., Alves, G. A. C., \& Faria, R. T. (2018). Criopreservação de sementes da orquídea brasileira em extinção Cattleya granulosa Lindl. Iheringia, Série Botânica, 73(2), 146-150. doi: 10.21826/2446-8231201873206

Zahara, M., Datta, A., Boonkorkaew, P., \& Mishra, A. (2017). The effects of different media, sucrose concentrations and natural additives on plantlet growth of Phalaenopsis Hybrid 'pink'. Brazilian Archives of Biology and Technology, 60(1), 1-15. doi: 10.1590/1678-4324-20171601 49 
